$$
\text { CONF-9605139--1 }
$$

submitted to Les Embiez Proceedings, Materials Science Forum, in press

\title{
Study of the Reactive Element Effect in ODS Iron-Base Alumina-Formers
}

\author{
B. A. Pint \\ Oak Ridge National Laboratory, P. O. Box 2008, Oak Ridge, TN 37831-6156, USA
}

\begin{abstract}
The Submitted manuscript has been authored dy a contractor of the U.S. Goverment under contractr DE-AC05-960R22464. Accordingly, the U.S. Goverment retains a nonexclusive, rublished form of license to publish or reproduce the published for U.S. this contribution, or allow Goverment purposes.
\end{abstract}

Keywords: reactive element effect, oxide dispersion strengthened, $\mathrm{FeCrAl}, \mathrm{Fe}_{3} \mathrm{Al}, \alpha-\mathrm{Al}_{2} \mathrm{O}_{3}$, scale adhesion, scale microstructure, interfacial voids

Abstract : Iron aluminide $\left(\mathrm{Fe}_{3} \mathrm{Al}\right)$ and $\mathrm{FeCrAl}$ compositions were dispersed with 15 different oxides in order to study the effect of oxygen-active dopants on the high-temperature growth and adhesion of $\alpha-\mathrm{Al}_{2} \mathrm{O}_{3}$ scales. In these model-type, oxide dispersion strengthened (ODS) systems, the chemical effects of various cation dopants were compared to the base-line effect of an $\mathrm{Al}_{2} \mathrm{O}_{3}$ oxide dispersion. By conducting isothermal and cyclic oxidation tests and by characterizing the oxidation product, effects on scale adhesion, growth rate and microstructure were evaluated. The dopants were categorized based on their effectiveness in modifying the alumina scale. $\mathrm{An} \mathrm{Al}_{2} \mathrm{O}_{3}$ dispersion yielded some improvement in oxidation behavior apparently by strengthening the relatively weak substrate. However, the type of improvements in adhesion and the change in growth mechanism associated with the addition of reactive elements such as $\mathrm{Y}$ were not achieved. In general, due to the weaker substrate and the inherently faster interfacial void formation, the dispersions were less effective in $\mathrm{ODS} F \mathrm{~F}_{3} \mathrm{Al}$ than in ODS FeCrAl.

Résumé : L'aluminide de fer $\left(\mathrm{Fe}_{3} \mathrm{Al}\right)$ et des composés $\mathrm{FeCrAl}$ ont été dispersés avec 15 dispersions d'oxyde différentes afin d'étudier l'effet de dopants actifs en oxygène sur la croissance à haute température et sur l'adhésion des couches $\alpha-\mathrm{Al}_{2} \mathrm{O}_{3}$. L'effet chimique de différents dopants cationiques dans ces systèmes modèles a été comparếs à l'effet de base d'une dispersion d'oxyde $\mathrm{Al}_{2} \mathrm{O}_{3}$. Les effets sur la croissance, la microstructure, et l'adhésion de la couche ont été évalués par d'essais isothermiques et cycliques d'oxydation, et par the characterization des produits de l'oxydation. Les dopants ont été catégorisés par les changes duns la microstructure de la couche $\mathrm{Al}_{2} \mathrm{O}_{3}$. Une dispersion $\mathrm{d}^{\prime} \mathrm{Al}_{2} \mathrm{O}_{3}$ améliore légèrement le comportement de l'oxydation uniquement en rendant plus solide le substrat relativement faible. Cependant, l'amélioration de l'adhésion et la modification du mécanisme de croissance liée à l'ajout d'éléments réactifs tel que Y n'a pas eu lieu. En général, à cause du substrat plus faible et de la formation de vides interfaciales naturellement plus rapide, les dispersions ont été moins éfficaces avec ODS $\mathrm{Fe}_{3} \mathrm{Al}$ qu'avec ODS FeCrAl.

\section{INTRODUCTION}

The study of the reactive element (RE) effect has a long and often confusing history. Attempts to develop a robust model for explaining the role of certain oxygen-active elements in improving scale adhesion, changing the scale growth mechanism and rate, and modifying the scale microstructure have been hampered by unpredictable results. For example, various studies have reported that any alloy dispersion ${ }^{1-7}$, and particularly $\mathrm{Al}_{2} \mathrm{O}_{3}{ }^{1-3,6}$, can produce the same effects as a $\mathrm{RE}$ oxide such as $\mathrm{Y}_{2} \mathrm{O}_{3}$. However, a model based on the RE acting as an interfacial dopant ${ }^{8,9}$ would suggest that the dispersoid composition is absolutely critical. Results indicating that an $\mathrm{Al}_{2} \mathrm{O}_{3}$ dispersion is just as effective as a RE oxide addition would be in direct conflict with such a model. Thus, a broad range of experiments was designed to evaluate various cation dispersions in $\mathrm{FeCrAl}$ and $\mathrm{Fe}_{3} \mathrm{Al}$ substrates. It was hoped that a well-distributed, sub-micron oxide dispersion could be considered a model system for evaluating the RE effect. Previous results have demonstrated that RE surface modifigationc10,11 
and RE alloy additions (due to second phase precipitation, e.g. Ref. 12) do not produce model systems for characterization.

This paper presents results from this ongoing program and attempts to briefly look at the overall effect and make some general conclusions about a range of cation dispersions. In both $\mathrm{Fe}_{3} \mathrm{Al}$ and $\mathrm{FeCrAl}$, an $\mathrm{Al}_{2} \mathrm{O}_{3}$ dispersion is found to modify the $\alpha-\mathrm{Al}_{2} \mathrm{O}_{3}$ scale. However, this effect can in no way be compared to the generally-established $\mathrm{RE}$ effect and is not a positive effect in long-term testing. Collectively, these results point to a role of the substrate mechanical properties in determining scale adhesion.

\section{EXPERIMENTAL PROCEDURE}

Gas-atomized $\mathrm{Fe}-28$ at.\%Al-2\% Cr (FAS) and $\mathrm{Fe}-20 \% \mathrm{Cr}-10 \% \mathrm{Al}$ (FCA) powder and sub-micron oxide or nitride (VN) powders were mechanically blended in a flowing Ar atmosphere using a watercooled, high-speed attritor and stainless steel balls. Standard dopant additions of 0.2 cation\% were made. FAS and FCA powders were milled without any addition to create an $\mathrm{Al}_{2} \mathrm{O}_{3}$ dispersion. The blended powder was canned, degassed, and extruded at $1100^{\circ} \mathrm{C}$. For comparison, FAS and FCA powders extruded without milling, cast $\mathrm{Fe}-28 \% \mathrm{Al}-2 \% \mathrm{Cr}$, commercial $\mathrm{ZrO}$-dispersed $\mathrm{Fe}-20 \% \mathrm{Cr}-$ $10.6 \% \mathrm{Al}$ alloy (Kanthal alloy $\mathrm{APM}$ ) and $\mathrm{Y}_{2} \mathrm{O}_{3}$-dispersed $\mathrm{Fe}-19 \% \mathrm{Cr}-8.4 \% \mathrm{Al}$ alloy (Inco alloy MA956) also were included in the study. Chemical compositions are given in Table I. Scanning electron microscopy (SEM) and transmission electron microscopy (TEM) of the as-extruded alloys consistently showed $\mathrm{a} \approx 1 \mu \mathrm{m}$ grain size and a bimodal particle distribution of $20-50 \mathrm{~nm}$ particles within grains and $0.2-1 \mu \mathrm{m}$ particles at grain boundaries. The number of larger particles generally increased with oxygen content.

Oxidation coupons $(10-15 \mathrm{~mm}$ diameter $\times 1 \mathrm{~mm}$ thick) were polished to $0.3 \mu \mathrm{m}$ alumina and ultrasonically cleaned in acetone and methanol prior to oxidation. Isothermal oxidation experiments were conducted in dry, flowing $\mathrm{O}_{2}$ at $1200^{\circ} \mathrm{C}$ with weight gains measured by a Cahn model 1000

Table I Chemical analysis of the as-extruded alloys. Dopant concentrations (in atomic percent) were determined by inductively coupled plasma analysis. Sulfur and oxygen contents were determined by combustion analysis.

\begin{tabular}{|c|c|c|c|c|c|c|c|c|c|}
\hline FCA: & $\begin{array}{c}\text { dopant } \\
(\mathrm{at} \%)\end{array}$ & $\mathrm{S}(\mathrm{ppm})$ & $\mathrm{O}(\mathrm{at} \%)$ & $\begin{array}{l}\text { Other } \\
\text { (at\%) }\end{array}$ & FAS: & $\begin{array}{c}\text { dopant } \\
\text { (at\%) }\end{array}$ & $S(p p m)$ & $O(a t \%)$ & $\mathrm{Ti}(\mathrm{at} \%)$ \\
\hline Extruded & $0.006 \mathrm{Zr}$ & 25 & 0.08 & $0.003 \mathrm{Hf}$ & Cast & $<0.01 \mathrm{Y}$ & 29 & 0.01 & $<0.01$ \\
\hline $\mathrm{Al}_{2} \mathrm{O}_{3}-1$ & $0.006 \mathrm{Zr}$ & 22 & 1.37 & $<0.01 \mathrm{Y}$ & Extruded & $<0.01 \mathrm{Y}$ & 48 & 0.10 & 0.08 \\
\hline $\mathrm{Al}_{2} \mathrm{O}_{3}-2$ & \multicolumn{4}{|c|}{ not analyzed } & $\mathrm{Al}_{2} \mathrm{O}_{3}-1$ & $<0.01 \mathrm{Y}$ & 61 & 6.33 & 0.07 \\
\hline$\overline{\mathrm{Ca}}$ & \multicolumn{4}{|c|}{ not analyzed } & $\mathrm{Al}_{2} \mathrm{O}_{3}-2$ & $<0.01 \mathrm{Y}$ & 62 & 2.34 & 0.08 \\
\hline$\overline{\mathrm{Ce}}$ & 0.19 & 23 & 1.91 & & $\mathrm{Al}_{2} \mathrm{O}_{3}-3$ & $<0.01 \mathrm{Y}$ & 24 & 1.32 & $<0.01$ \\
\hline$\overline{G d}$ & 0.19 & 24 & 1.86 & $0.01 \mathrm{Ti}$ & $\mathrm{Ce}$ & 0.19 & 53 & 4.88 & 0.08 \\
\hline $\mathrm{Hf}$ & 0.19 & 27 & 1.89 & & Hf & 0.18 & 24 & 1.63 & $<0.01$ \\
\hline$\overline{\mathrm{Mg}}$ & 0.19 & 20 & 1.40 & & $\mathrm{La}$ & 0.16 & 62 & 4.23 & 0.06 \\
\hline $\mathrm{Mn}$ & 0.23 & 24 & 1.70 & & $\mathrm{Nd}$ & 0.17 & 60 & 2.39 & 0.08 \\
\hline $\mathrm{Nb}$ & 0.19 & 22 & 1.99 & & Sc & 0.19 & 23 & 1.90 & $<0.01$ \\
\hline Nd & 0.15 & 23 & 1.84 & & $\mathrm{Y}$ & 0.19 & 49 & 3.03 & 0.07 \\
\hline$\overline{\mathrm{Sc}}$ & 0.16 & 29 & 1.79 & & $\mathrm{Y}$ & 0.17 & 21 & 2.03 & $<0.01$ \\
\hline $\mathrm{Si}$ & \multicolumn{4}{|c|}{ not analyzed } & $\mathrm{Yb}$ & 0.29 & 63 & 3.67 & 0.07 \\
\hline $\mathrm{Ta}$ & 0.17 & 21 & 1.93 & $0.02 \mathrm{Ce}$ & $\overline{\mathrm{Zr}}$ & 0.17 & 70 & 2.73 & 0.07 \\
\hline $\mathrm{Ti}$ & 0.20 & 22 & 4.46 & & & & & & \\
\hline $\mathrm{V}(\mathrm{N})$ & \multicolumn{4}{|c|}{ not analyzed } & & & & & \\
\hline $\mathrm{Y}$ & 0.18 & 25 & 3.85 & & & & & & \\
\hline $\mathrm{Yb}$ & \multicolumn{4}{|c|}{ not analyzed } & & & & & \\
\hline$Y$ in MA956 & 0.30 & 110 & 0.66 & $0.39 \mathrm{Ti}$ & & & & & \\
\hline $\mathrm{Zr}$ in $\mathrm{APM}$ & 0.06 & 10 & 0.17 & $0.43 \mathrm{Si}$ & & & & & \\
\hline
\end{tabular}


microbalance. Cyclic oxidation experiments were conducted at $1200^{\circ} \mathrm{C}$ and $1300^{\circ} \mathrm{C}$ in air and in dry flowing $\mathrm{O}_{2}$. In short-term cyclic testing ( $2 \mathrm{~h}$ cycles), specimens were hung in a furnace and exposed to dry, flowing $\mathrm{O}_{2}$. In long-term testing ( $100 \mathrm{~h}$ cycles), specimens were placed in the furnace in preannealed alumina crucibles so that spalled oxide could be collected and weighed. In both types of cyclic tests, the specimen weight changes were measured before and after oxidation using a Mettler model AE240 balance. After oxidation, specimens were examined using SEM and energy dispersive $\mathrm{X}$-ray analysis (SEM/EDXA). Selected samples were analyzed using TEM equipped with EDXA.

\section{RESULTS}

An initial screening test of $20,2 \mathrm{~h}$ cycles at $1200^{\circ} \mathrm{C}$ was used in order to assess the performance of the various alloys. Sample weight change data for the FAS-based alloys are shown in Figure 1. The final weight changes after 20 cycles for the FCA-based alloys are given in Table II. The highest $\mathrm{Al}_{2} \mathrm{O}_{3}$ addition in $\mathrm{FAS}, \mathrm{Al}_{2} \mathrm{O}_{3}-1$ in Table $\mathrm{I}$, showed little spallation during the 20 cycles and behaved similarly to Kanthal APM. This is in marked contrast to the extruded, undoped FAS which produced a very fine spall and eventually lost weight during the 20 cycles. Comparison of scale morphologies on FAS with and without an $\mathrm{Al}_{2} \mathrm{O}_{3}$ addition after a $2 \mathrm{~h}$ exposure at $1200^{\circ} \mathrm{C}$ (Figure 2) showed that the highly convoluted scale is flattened by the addition of an $\mathrm{Al}_{2} \mathrm{O}_{3}$ dispersion. This scale flattening improves adhesion in short-term testing. A lower $\mathrm{Al}_{2} \mathrm{O}_{3}$ addition, $\mathrm{Al}_{2} \mathrm{O}_{3}-2$ also produced a flat scale after $2 \mathrm{hr}$, but spalled readily after a few $2 \mathrm{~h}$ cycles. In general, all of the oxide additions initially produced a flat scale. Comparing the scale fracture cross-section of $\mathrm{Al}_{2} \mathrm{O}_{3}$-dispersed $\mathrm{FAS}$ with that of $\mathrm{Y}_{2} \mathrm{O}_{3}$-dispersed FAS after $2 \mathrm{~h}$ at $1200^{\circ} \mathrm{C}$, Figure 3, it is clear that the $\mathrm{Al}_{2} \mathrm{O}_{3}$ dispersion does not produce a columnar alumina structure as observed in RE-doped scales ${ }^{14,15}$. In long-term testing (100h cycles) at $1200^{\circ} \mathrm{C}$ and $1300^{\circ} \mathrm{C}$ in air ${ }^{13}, \mathrm{Al}_{2} \mathrm{O}_{3}$-dispersed $\mathrm{FAS}$ alloys had a significantly reduced lifetime compared to cast, undoped FAS with a similar thickness. Coupons went into breakaway oxidation after 5-7 100h cycles. This is believed to be due to the coarsening of fine $\mathrm{Al}_{2} \mathrm{O}_{3}$ particles

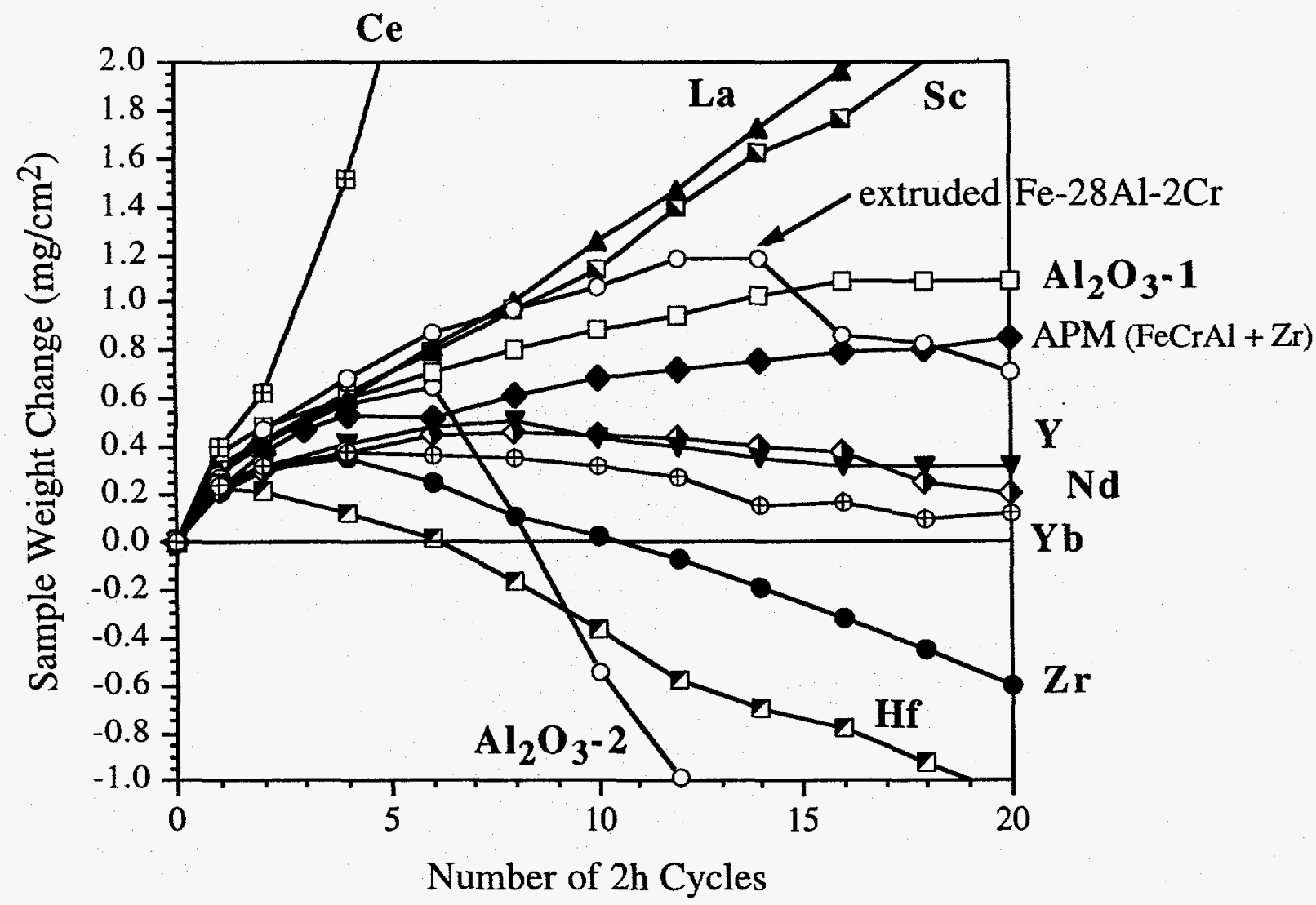

Figure 1. Weight change of $\mathrm{Fe}-28 \mathrm{Al}-2 \mathrm{Cr}$ (FAS) with various cation oxide dispersions $(0.2$ at $\%)$ cycled from room temperature to $1200^{\circ} \mathrm{C}$ with a cycle time at temperature of $2 \mathrm{~h}$. None of the alloys perform as well as $\mathrm{ZrO}_{2}$-dispersed $\mathrm{FeCrAl}$. 
Table II. Current experimental results from cyclic and isothermal testing of oxide-dispersed $\mathrm{FeCrAl}$ with various 0.2 cation $\%$ additions.

\begin{tabular}{|c|c|c|c|c|c|c|c|c|}
\hline $\begin{array}{c}\text { FeCrAl } \\
\text { with oxide } \\
\text { dispersions } \\
\text { of: }\end{array}$ & $\begin{array}{l}\text { Sample } \\
\text { Weight } \\
\text { Change } \\
1200^{\circ} \mathrm{C} \\
20 \times 2 \mathrm{~h} \\
\mathrm{mg} / \mathrm{cm}^{2}\end{array}$ & $\begin{array}{c}\text { Total } \\
\text { Weight } \\
\text { Gain } \\
1200^{\circ} \mathrm{C} \\
1 \times 100 \mathrm{~h} \\
\mathrm{mg} / \mathrm{cm}^{2}\end{array}$ & $\begin{array}{c}\text { Spalled } \\
\text { Weight } \\
1200^{\circ} \mathrm{C} \\
1 \times 100 \mathrm{~h} \\
\mathrm{mg} / \mathrm{cm}^{2}\end{array}$ & $\begin{array}{c}\text { Total } \\
\text { Weight } \\
\text { Change } \\
1300^{\circ} \mathrm{C} \\
1 \times 100 \mathrm{~h} \\
\mathrm{mg} / \mathrm{cm}^{2}\end{array}$ & $\begin{array}{c}\text { Spalled } \\
\text { Weight } \\
1300^{\circ} \mathrm{C} \\
1 \times 100 \mathrm{~h} \\
\mathrm{mg} / \mathrm{cm}^{2}\end{array}$ & $\begin{array}{c}1200^{\circ} \mathrm{C} \\
\text { Isothermal } \\
\text { Parabolic } \\
\text { Rate } \\
\times 10^{-12} \\
\left(\mathrm{~g}^{2} / \mathrm{cm}^{4} \mathrm{~s}\right)\end{array}$ & $\begin{array}{c}\text { Scale } \\
\text { Structure } \\
\text { after } 100 \mathrm{~h} \\
\text { at } 1300^{\circ} \mathrm{C}\end{array}$ & \begin{tabular}{|c} 
Ionic \\
Radius \\
$(\AA)$ \\
6-fold \\
coordi- \\
nation
\end{tabular} \\
\hline Undoped & $\begin{array}{r}1.79^{\mathrm{a}} \\
-5.48^{\mathrm{b}} \\
\end{array}$ & 2.33 & 2.31 & $\begin{array}{l}4.43 \\
3.33 \\
\end{array}$ & $\begin{array}{l}4.21 \\
3.86 \\
\end{array}$ & $\begin{array}{c}27 \\
12^{\mathrm{b}} \\
\end{array}$ & equiaxed & N/A \\
\hline $\begin{array}{l}(1) \\
(2)\end{array}$ & $\begin{array}{l}-0.09 \\
-0.69\end{array}$ & $\begin{array}{l}\text { n.t. } \\
1.61\end{array}$ & $\begin{array}{l}\text { n.t. } \\
3.10\end{array}$ & $\begin{array}{l}5.57 \\
2.99\end{array}$ & $\begin{array}{l}13.79 \\
2.03\end{array}$ & $\begin{array}{l}\text { n.t. } \\
20\end{array}$ & equiaxed & 0.53 \\
\hline $\mathrm{Ca}$ & 0.75 & n.t. & n.t. & n.t. & n.t. & n.t. & n.t. & 1.00 \\
\hline$\overline{\mathrm{Ce}}$ & n.t. & 13.30 & 0 & 3.30 & 5.71 & $\mathrm{c}$ & columnar & 0.87 \\
\hline$\overline{\mathrm{Gd}}$ & 0.77 & 1.55 & 0 & 3.42 & 0.55 & 6.8 & columnar & 0.94 \\
\hline$\overline{\mathrm{Hf}}$ & n.t. & 2.79 & 0.01 & 4.61 & 1.04 & n.t. & convoluted & $0.83^{\mathrm{d}}$ \\
\hline $\mathrm{Mg}$ & 1.15 & 1.99 & 0.06 & 3.50 & 6.23 & 9.4 & equiaxed & 0.72 \\
\hline $\mathrm{Mn}$ & 0.93 & 1.62 & 3.39 & 3.06 & 6.14 & n.t. & equiaxed & $0.67^{e}$ \\
\hline $\mathrm{Nb}$ & 0.79 & 1.51 & 2.96 & n.t. & n.t. & 12 & n.t. & 0.72 \\
\hline $\mathrm{Nd}$ & 0.90 & 1.35 & 0 & 3.27 & 5.21 & n.t. & columnar & 0.98 \\
\hline Sc & 1.24 & 2.37 & 0.01 & 5.83 & 0.02 & 5.9 & convoluted & 0.75 \\
\hline$\overline{\mathrm{Si}}$ & $2.72^{a}$ & $4.38^{\mathrm{a}}$ & 1.34 & n.t. & n.t. & $a$ & n.t. & $0.26^{f}$ \\
\hline $\mathrm{Ta}$ & 0.88 & 1.88 & 1.59 & 3.40 & 5.45 & 18 & equiaxed & 0.64 \\
\hline $\mathrm{Ti}$ & 0.91 & n.t. & n.t. & 2.78 & 1.44 & $\mathrm{a}$ & equiaxed & 0.61 \\
\hline $\mathrm{V}(\mathrm{N})$ & 0.28 & n.t. & n.t. & n.t. & n.t. & n.t. & n.t. & 0.64 \\
\hline $\mathrm{Y}$ & 1.16 & 1.74 & 0.20 & 2.62 & 0.41 & n.t. & columnar & 0.90 \\
\hline $\mathrm{Yb}$ & 0.69 & 1.78 & 0.18 & n.t. & n.t. & n.t. & n.t. & 0.87 \\
\hline $\mathrm{Y}$ in MA956 & $0.84 \mathrm{~g}$ & 1.59 & 0.05 & 3.39 & 0.13 & $3.4-4.1^{g}$ & columnar & 0.90 \\
\hline $\mathrm{Zr}$ in $\mathrm{APM}$ & $0.85 \mathrm{~g}$ & 1.36 & 0 & 2.82 & 0.0 & $3.0-4.5^{g}$ & columnar & $0.84^{\mathrm{d}}$ \\
\hline $\begin{array}{l}\text { n.t. : not test } \\
\text { a : substantia } \\
b \text { : data for a } \\
c \text { : went into }\end{array}$ & & & $\mathrm{r} 15 \mathrm{hr}$ & & $\begin{array}{l}\text { fold co } \\
\mathrm{Mn}^{2+}\end{array}$ & ination & & \\
\hline
\end{tabular}

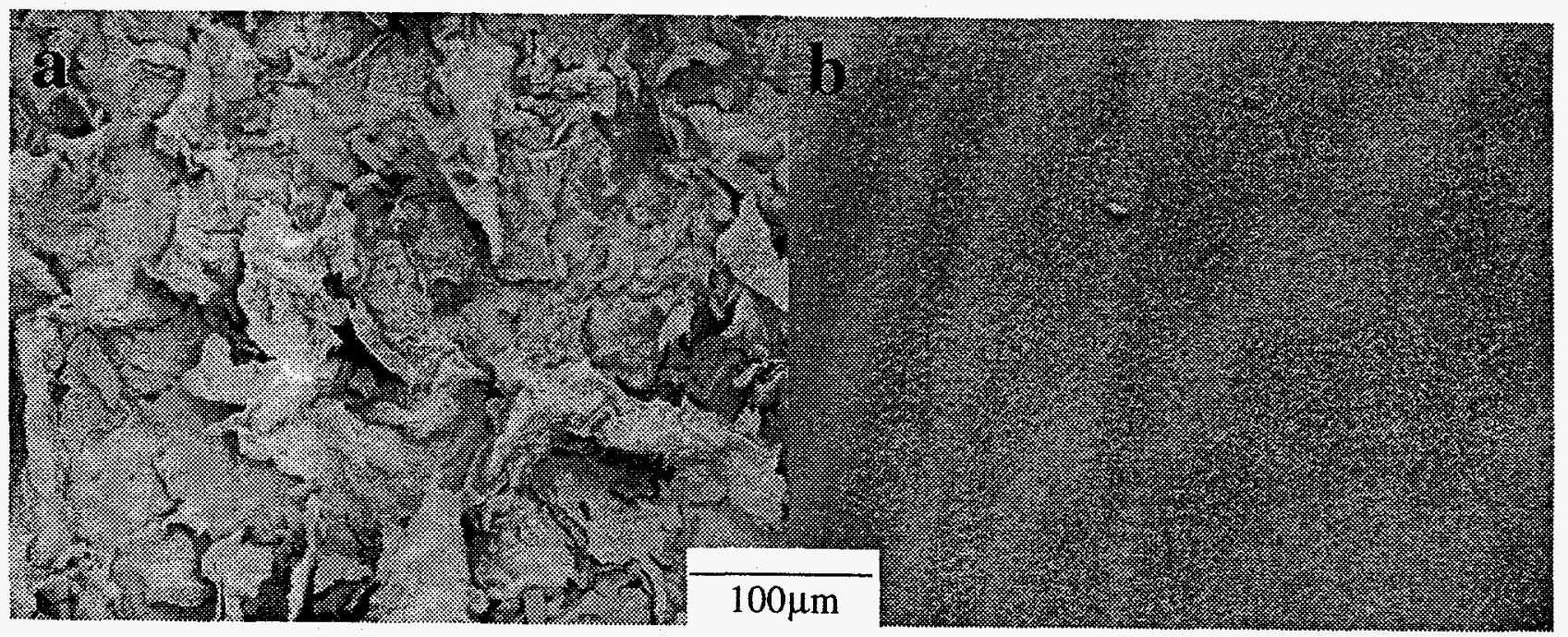

Figure 2. SEM secondary electron images of the scale surface after $2 \mathrm{~h}$ at $1200^{\circ} \mathrm{C}$ in $\mathrm{O}_{2}$ (a) unmilled, extruded $\mathrm{Fe}-28 \mathrm{Al}-2 \mathrm{Cr}$ powder, (b) milled, extruded powder which contains an $\mathrm{Al}_{2} \mathrm{O}_{3}$ dispersion. The alumina scale is flattened by the addition of an $\mathrm{Al}_{2} \mathrm{O}_{3}$ dispersion. 


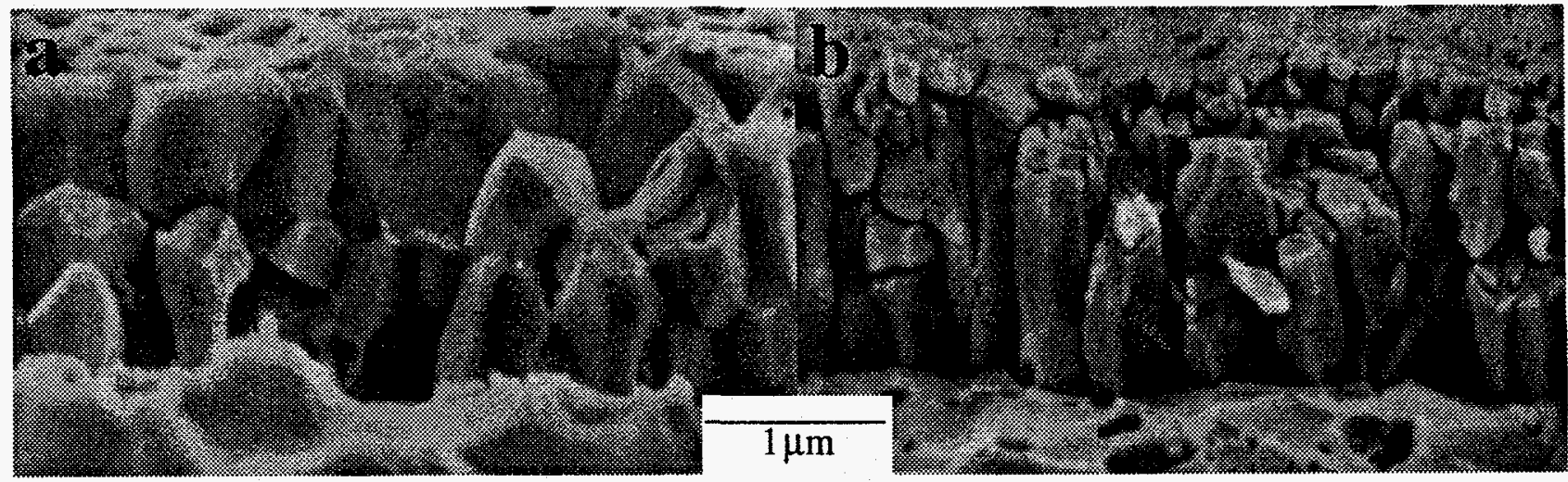

Figure 3. SEM secondary electron images of the alumina scale fracture cross-section after $2 \mathrm{~h}$ at $1200^{\circ} \mathrm{C}$ in $\mathrm{O}_{2}$ grown on $\mathrm{Fe}-28 \mathrm{Al}-2 \mathrm{Cr}$ containing a dispersion of (a) $\mathrm{Al}_{2} \mathrm{O}_{3}$ and (b) $\mathrm{Y}_{2} \mathrm{O}_{3}$. $\mathrm{The}_{2} \mathrm{Al}_{2} \mathrm{O}_{3}$ dispersion does not have the columnar grain structure typical of RE-doped $\alpha-\mathrm{Al}_{2} \mathrm{O}_{3}$ scales.

and the larger particles allowing rapid $O$ transport into the substrate ${ }^{16,17}$.

As reported more fully elsewhere ${ }^{13}, \mathrm{RE}$ additions (alloy additions or oxide dispersions) are not as effective in improving scale adhesion in $\mathrm{Fe}_{3} \mathrm{Al}$ as in other alumina-forming alloys such as $\beta$-NiAl or $\mathrm{FeCrAl}$. Therefore, it is difficult to define a baseline improvement in performance (such as that produced by a $\mathrm{Y}_{2} \mathrm{O}_{3}$ addition) in order to evaluate the various additions. However, it is possible to make a few observations. Added as 0.2 cation\%, Ce, La and $\mathrm{Sc}$ caused an acceleration of the isothermal growth rate and these alloys are considered "over-doped". By lowering these contents, the negative effects were minimized ${ }^{13}$. $\mathrm{Nd}$ and $\mathrm{Yb}$ performed similarly to $\mathrm{Y}$ in short-term cycling, while $\mathrm{Hf}$ and $\mathrm{Zr}$ performed slightly less favorably. In long term testing $\left(10 \times 100 \mathrm{~h}\right.$ cycles at $\left.1200^{\circ} \mathrm{C}\right)$, none of these additions performed as well as $\mathrm{Y}^{13}$. All of these doped alloys appear to form a high concentration of interfacial voids, such as those in Figure 4, which grow with time and lead to scale spallation.

More additions were made to FCA than FAS because, as demonstrated by commercial ODS FeCrAl alloys, RE oxide dispersions are very effective in improving oxidation resistance in this system. Similar to observations in $\mathrm{FAS}, \mathrm{Al}_{2} \mathrm{O}_{3}$ dispersions were found to flatten the scale but produce none of the other RE effects. The $\mathrm{Al}_{2} \mathrm{O}_{3}$-dispersed $\mathrm{FCA}$ alloys performed better than the cast and extruded undoped FeCrAl alloys during $20 \times 2 \mathrm{~h}$ cycles, Table II, but still spalled readily. The $\mathrm{Al}_{2} \mathrm{O}_{3}$ dispersion did not reduce the growth rate or produce a columnar alumina scale.

For the various cation dopants, a comparison can be made with the commercial alloys containing $\mathrm{Y}_{2} \mathrm{O}_{3}$ and $\mathrm{ZrO}_{2}$. In this case, the $2 \mathrm{~h}$ cyclic test was insufficient to differentiate performance. The majority of dopants (except $\mathrm{VN})$ showed little spallation during $20 \times 2 \mathrm{~h}$ cycles. A more severe adhesion test with $100 \mathrm{~h}$ cycles at $1200^{\circ} \mathrm{C}$ and $1300^{\circ} \mathrm{C}$ is required. This testing is in progress using alumina crucibles in air. The results from the first cycle at each temperature are reported in Table II. The total weight gain (sample + spalled oxide) gives some information about the scale growth rate while the weight of spall gives some measure of scale adhesion. The scale microstructure after $100 \mathrm{~h}$ at $1300^{\circ} \mathrm{C}$ was examined by SEM in order to assess the effect of the various cations. Figure 5 illustrates examples of the columnar- and equiaxed-type

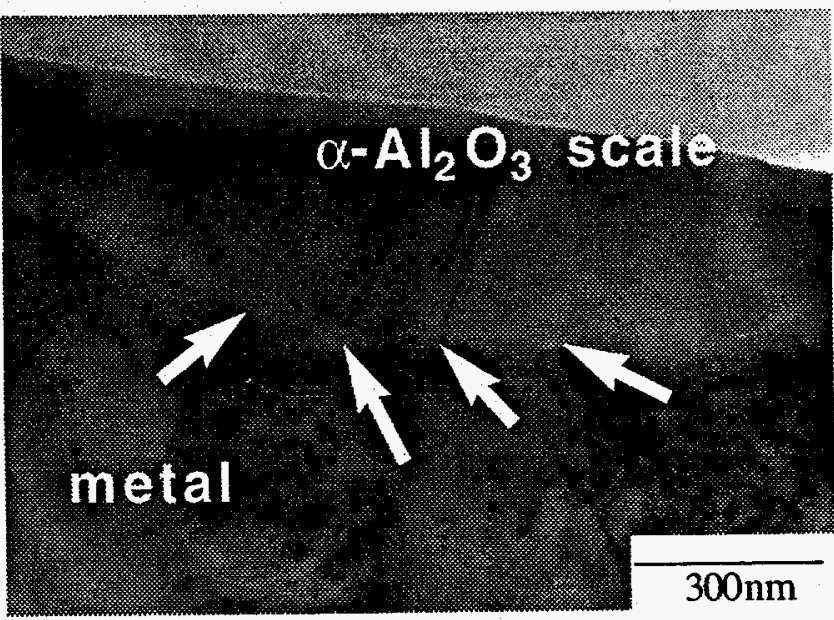

Figure 4. TEM bright field image of the metalscale interface of $\mathrm{Y}_{2} \mathrm{O}_{3}$-dispersed $\mathrm{Fe}-28 \mathrm{Al}-2 \mathrm{Cr}$ after $2 \mathrm{~h}$ at $1200^{\circ} \mathrm{C}$ in $\mathrm{O}_{2}$. The arrows mark interfacial voids ${ }^{18}$. 
cross sections that were observed.

There is a great deal of information contained in Table II and a story could be told about each particular dopant. In brief, oxide additions of $\mathrm{Mn}, \mathrm{Nb}, \mathrm{Ta}, \mathrm{Ti}$ and $\mathrm{V}$ did not clearly produce any $\mathrm{RE}$ effects. It is interesting to note that these additions performed better than just an $\mathrm{Al}_{2} \mathrm{O}_{3}$ dispersion. Apparently 0.2 cation \% additions of $\mathrm{Ce}, \mathrm{Hf}$ and $\mathrm{Sc}$ over-doped $\mathrm{FeCrAl}$. These additions accelerated the oxidation rate and produced convoluted alumina scales. However, they did appear to improve scale adhesion and therefore are likely to produce improved results when added in lower quantities. These elements are being reevaluated with 0.05 cation $\%$ additions. At this time there is insufficient evidence to fully evaluate $\mathrm{Ca}, \mathrm{Si}$, and $\mathrm{Yb}$. Additions of $\mathrm{Gd}$ and $\mathrm{Nd}$ achieved many of the same improvements associated with additions of $\mathrm{Y}$ and $\mathrm{Zr}$. They improved scale adhesion (Gd more so than $\mathrm{Nd}$ ) and produced a columnar alumina scale. While $\mathrm{Gd}$ and $\mathrm{Nd}$ did not appear to be as effective as $\mathrm{Y}$ and $\mathrm{Zr}$ in commercial ODS FeCrAls, the 0.2 cation\% may not be an optimum addition. Magnesium represents an interesting case in that it is a small ion which appeared to improve scale adhesion but did not substantially change the scale growth rate or microstructure.

\section{DISCUSSION}

In both FCA and FAS substrates, the main effect of an $\mathrm{Al}_{2} \mathrm{O}_{3}$ dispersion appears to be flattening the alumina scale. The flatter scale appears to be more adherent in short-term testing. This improvement may be the central reason that previous reports attributed beneficial effects to an $\mathrm{Al}_{2} \mathrm{O}_{3}$ dispersion. However, the $\mathrm{Al}_{2} \mathrm{O}_{3}$ dispersion did not produce a sustained improvement in scale adhesion. When a thicker scale was grown $\left(100 \mathrm{~h}\right.$ at $\left.1200^{\circ} \mathrm{C}\right)$, the alumina scale spalled readily from $\mathrm{Al}_{2} \mathrm{O}_{3}$-dispersed FAS and FCA. The $\mathrm{Al}_{2} \mathrm{O}_{3}$ dispersion produced no change in the scale grain structure (Figure 3 and

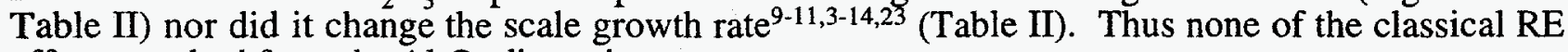
effects resulted from the $\mathrm{Al}_{2} \mathrm{O}_{3}$ dispersion.

It is commonplace now to correlate indigenous sulfur with effects on scale adhesion ${ }^{19-21}$. The inability of $\mathrm{Y}$ and $\mathrm{Zr}$ additions in $\mathrm{Fe}_{3} \mathrm{Al}$ to improve long-term scale adhesion suggests that there is more involved than just sulfur gettering. Many of the sulfur studies have been conducted on Ni-base superalloys which have excellent high temperature strength. Cast FAS and FCA have very poor strength at high temperature. A weak substrate may aid in the initiation of scale convolutions which
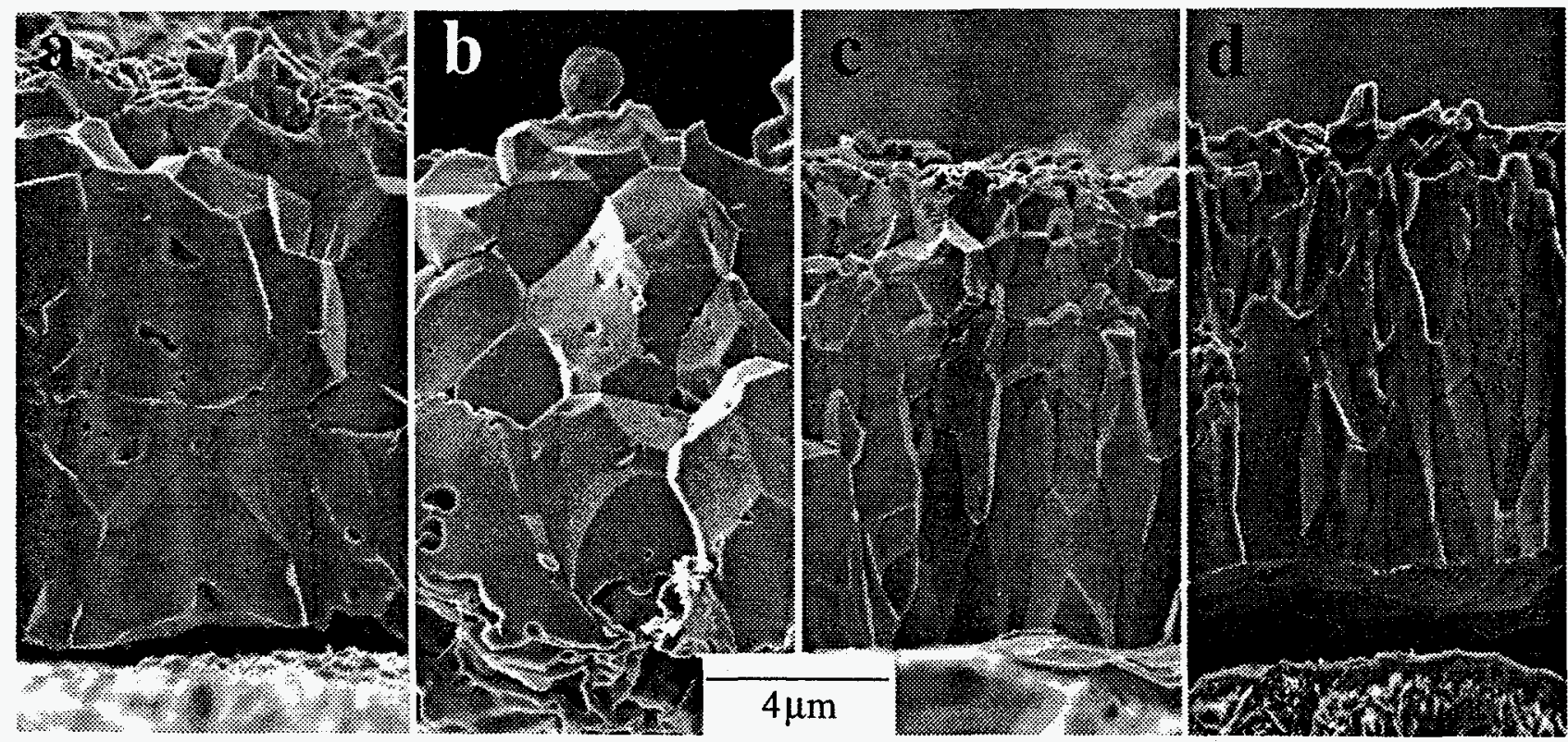

Figure 5. SEM secondary electron images of $\alpha-\mathrm{Al}_{2} \mathrm{O}_{3}$ scale fracture cross-sections after $100 \mathrm{~h}$ at $1300^{\circ} \mathrm{C}$ in air on $\mathrm{Fe}-20 \mathrm{Cr}-10 \mathrm{Al}$ doped with (a) $\mathrm{MnO}_{2}$, (b) $\mathrm{Ta}_{2} \mathrm{O}_{5}$, (c) $\mathrm{CeO}_{2}$ and (d) $\mathrm{Nd}_{2} \mathrm{O}_{3}$. The equiaxed structure in (a) \& (b) is typical of undoped $\alpha-\mathrm{Al}_{2} \mathrm{O}_{3}$, while the columnar structure illustrated in (c) \& (d) is typical of RE-doped $\alpha-\mathrm{Al}_{2} \mathrm{O}_{3}$, growing predominantly by anion boundary diffusion. 

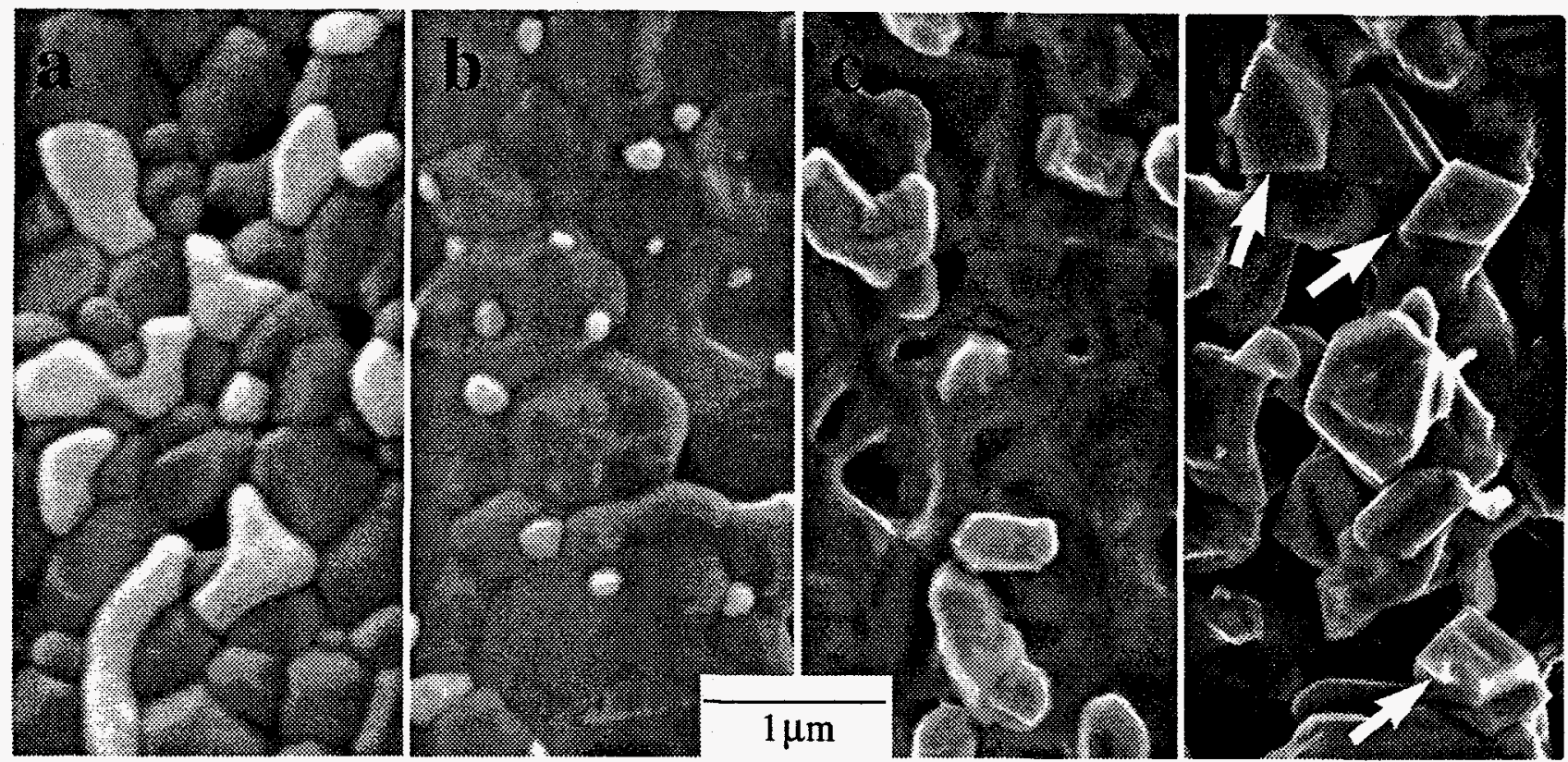

Figure 6. SEM secondary electron images of the $\alpha-\mathrm{Al}_{2} \mathrm{O}_{3}$ scale surface after $100 \mathrm{~h}$ at $1300^{\circ} \mathrm{C}$ in air on with (a) $\mathrm{Yb}_{2} \mathrm{O}_{3}$-dispersed $\mathrm{Fe}$-28Al-2Cr, (b) $\mathrm{HfO}_{2}$-dispersed $\mathrm{Fe}$-28Al-2Cr, (c) $\mathrm{Gd}_{2} \mathrm{O}_{3}$-dispersed $\mathrm{Fe}$ $20 \mathrm{Cr}-10 \mathrm{Al}$ and (d) $\mathrm{MgO}$-dispersed $\mathrm{Fe}-20 \mathrm{Cr}$-10Al. The particles in each image contain the dopant cation.

then grow more convoluted as a result of isothermal scale growth stresses. One effect of the $\mathrm{Al}_{2} \mathrm{O}_{3}$ dispersion may be to improve the creep strength of the substrate. Strengthening the substrate may inhibit isothermal scale growth stresses from deforming the substrate, leading to less-convoluted scales. A flatter scale allows better contact with the substrate. The short-term nature of the improvements with an $\mathrm{Al}_{2} \mathrm{O}_{3}$ dispersion may be due to a loss of strengthening from particle coarsening. However, when failure does occur it does not appear to be a result of scale convolutions but rather the growth of interfacial voids ${ }^{13}$. The combination of a strong substrate and a RE dopant to inhibit the growth of interfacial voids ${ }^{9,22}$ may be necessary to achieve good long-term performance in FAS and FCA. The requirement appears to be more severe in FAS due to the increased formation of interfacial voids compared to FCA. The addition of $\mathrm{Y}_{2} \mathrm{O}_{3}$ does not appear to be as effective in FAS as in FCA. The number and size of the interfacial voids observed on $\mathrm{Y}_{2} \mathrm{O}_{3}$-dispersed FAS (Figure 4) were much larger than the small $(20-50 \mathrm{~nm})$ voids observed on MA956 ${ }^{14}$. The alloys produced for this study may not have exhibited the best possible performance due to high $\mathrm{O}$ contents relative to commercial ODS alloys, Table I. However, attempts to reduce the $\mathrm{O}$ content in FAS (for $\mathrm{Y}_{2} \mathrm{O}_{3}$ additions and for $\mathrm{Al}_{2} \mathrm{O}_{3}$ additions) have resulted in worse performance ${ }^{13}$.

Determining the characteristics of RE dopants is a difficult task. There always seems to be some exception to each model. Large ions (Table II) appear to be effective RE dopants, thus one would expect $\mathrm{Gd}$ and $\mathrm{Nd}$ to have positive effects. However, the relatively small $\mathrm{Sc}$ ion also appears to be beneficial. The observation of $\mathrm{Sc}$ ions segregated to $\alpha-\mathrm{Al}_{2} \mathrm{O}_{3}$ grain boundaries ${ }^{18}$ helps to explain its effectiveness. Recently, it was proposed ${ }^{9}$ that RE dopants are effective because they are driven by the oxygen potential gradient to diffuse from the alloy (even when added as RE oxides) into the scale, leading to the nucleation of RE-rich oxides at the gas interface of the scale. This behavior was observed for all of the elements which were effective in improving scale adhesion. Examples of RErich particles at the gas interface are shown in Figure 6. This model would suggest that elements with high oxygen affinity (e.g. high free energy of oxide formation) would make effective dopants. However, the most oxygen active elements are also generally the most sulfur active elements. Thus, this criterion is not specific in determining if sulfur gettering is instead the most important factor.

The correlation between a columnar structure and lower growth rate, due to the suppression of $\mathrm{Al}$ boundary transport ${ }^{23}$, appeared to hold for this set of experiments. When growth occurs by both $\mathrm{Al}$ and $\mathrm{O}$ transport, a higher growth rate was coupled with an equiaxed scale grain structure. This was 
observed for dispersions of $\mathrm{Al}_{2} \mathrm{O}_{3}, \mathrm{Ta}_{2} \mathrm{O}_{5}$ and $\mathrm{MgO}$. Future work will continue to look at this correlation and others, in order to more fully understand the RE effect.

\section{CONCLUSIONS}

1. For the oxidation of oxide-dispersed $\mathrm{FeCrAl}$ and $\mathrm{Fe}_{3} \mathrm{Al}$ at $1200^{\circ} \mathrm{C}$, the chemical composition of the dispersoid is a critical determinant for performance.

2. At $1200^{\circ} \mathrm{C}$ and $1300^{\circ} \mathrm{C}$, the major observable features of a fully effective RE addition in these alloys are improved scale adhesion, a reduced growth rate, a columnar scale grain structure and $\mathrm{RE}$-rich oxide particles at the gas interface of the scale.

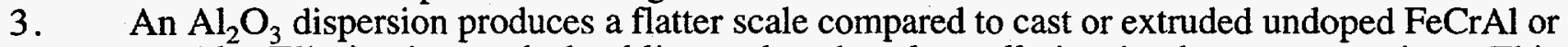
$\mathrm{Fe}_{3} \mathrm{Al}$. Eliminating scale buckling reduced scale spallation in short-term testing. This improvement may be the central reason that previous reports attributed beneficial effects to an $\mathrm{Al}_{2} \mathrm{O}_{3}$ dispersion. However, in long term testing, an $\mathrm{Al}_{2} \mathrm{O}_{3}$ dispersion produced adverse effects.

4. Short-term testing was not sufficient to determine the efficacy of various cation dopants. Long term testing is required in order to assess performance.

5. Oxide-dispersed $\mathrm{Fe}_{3} \mathrm{Al}$ is not a good model system for studying the reactive element effect because of excessive interfacial void formation. However, oxide-dispersed $\mathrm{FeCrAl}$ appears to be promising in this regard.

\section{ACKNOWLEDGMENTS}

The author is thankful to J. R. DiStefano, P. F. Tortorelli and I. G. Wright for their comments on the manuscript and K. Blakely, L. D. Chitwood, M. Howell, J. Weaver and W. Jones for assistance with the experimental work. This research is supported by the U. S. Department of Energy's Distinguished Postdoctoral Research Program administered by the Oak Ridge Institute for Science and Education and the Fossil Energy AR\&TD Materials Program, U. S. Department of Energy, under contract DE-AC05-96OR22464 with Lockheed Martin Energy Research Corporation.

\section{REFERENCES}

1. Tien J. K., Pettit F. S., Met. Trans. 3 (1972) 1587

2. Wright I. G., Wilcox B. A., Jaffe R. I., Oxid. Met. 9 (1975) 275

3. Michels H. T., Met. Trans. 7A (1976) 379

4. Allam I. A., Whittle D. P., Stringer J., Oxid. Met. 13 (1979) 381

5. Goncel O. T., Whittle D. P., Stringer J., Corr. Sci. 19 (1979) 287

6. $\quad$ Kingsley L. M., Stringer J., Oxid. Met. 32 (1989) 371

7. Whittle D. P., Stringer, J., Phil. Trans. Royal Soc. A 295 (1980) 309

8. Przybylski K., Yurek G. J., Materials Science Forum 43 (1989) 1

9. Pint B. A., Oxid. Met. 45 (1996) 1

10. Pint B. A., MRS Bull. 19(10) (1994) 26

11. Pint B. A., Hobbs L. W., J. Electrochem. Soc. 141 (1994) 2443

12. Kuenzly J. D., Douglass D. L., Oxid. Met. 8 (1974) 139

13. Pint. B. A., Tortorelli P. F., Wright, I. G., submitted to Werk. Korr. (1996)

14. Pint B. A., Garratt-Reed A. J., Hobbs L. W., Mat. High Temp. 13 (1995) 3

15. Golightly F. A., Stott F. H., Wood G. C., J. Electrochem. Soc. 126 (1979) 1035

16. Doychak J., Nesbitt J. A., Noebe R. D., Bowman R. R., Oxid. Met. 38 (1992) 45

17. Tortorelli P. F., DeVan J. H., McKamey C. G., Howell M., Ceram Trans. 19 (1991) 961

18. Alexander K. B., Pint B. A., unpublished research (1996)

19. Funkenbush A. W., Smeggil J. G., Bornstein N. S., Met. Trans. 16A (1985) 1164

20. Smialek J. L., Met. Trans. 22A (1991) 739

21. Sigler D. R., Oxid. Met. 32 (1989) 337

22. Grabke H. J., Weimer D., Viefhaus H., App. Surf. Sci. 47 (1991) 243

23. Pint B. A., Martin J. R., Hobbs L. W., Oxid. Met. 39 (1993) 167 


\section{DISCLAIMER}

This report was prepared as an account of work sponsored by an agency of the United States Government. Neither the United States Government nor any agency thereof, nor any of their employees, makes any warranty, express or implied, or assumes any legal liability or responsibility for the accuracy, completeness, or usefulness of any information, apparatus, product, or process disclosed, or represents that its use would not infringe privately owned rights. Reference herein to any specific commercial product, process, or service by trade name, trademark, manufacturer, or otherwise does not necessarily constitute or imply its endorsement, recommendation, or favoring by the United States Government or any agency thereof. The views and opinions of authors expressed herein do not necessarily state or reflect those of the United States Government or any agency thereof. 


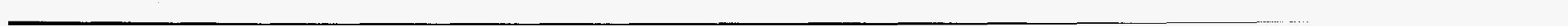

